\title{
Metabolically active bacteria in Lake Kinneret
}

\author{
T. Berman ${ }^{1, *}$, B. Kaplan ${ }^{1}$, S. Chava ${ }^{1}$, Y. Viner $^{1}$, B. F. Sherr ${ }^{2}$, E. B. Sherr ${ }^{2}$ \\ ${ }^{1}$ Israel Oceanographic and Limnological Research, The Yigal Allon Kinneret Limnological Laboratory, \\ PO Box 345, Tiberias 14 102, Israel \\ ${ }^{2}$ College of Oceanic and Atmospheric Sciences, Oregon State University, Corvallis, Oregon 97330-5503, USA
}

\begin{abstract}
Three staining methods were used to identify metabolically active bacteria in Lake Kinneret, northern Israel: CTC, DAPI staining followed by a propanol wash, and the Molecular Probes Live/Dead stain. Positive results from these methods purport to show, respectively, actively respiring bacteria (CTC+), cells with intact nucleoids (NuCC), and cells with intact membranes (MEM+). Concomitantly, bacterial metabolic activity was measured as electron transport system (ETS) flux, $\mathrm{O}_{2}$ uptake, activities of peptidase, $\beta$-glucosidase and lipase, and rate of leucine incorporation in monthly samples taken for $2.5 \mathrm{yr}$ at a pelagic lake station. Laboratory experiments followed changes during 22 or $40 \mathrm{~h}$ in the percentages of 'active' bacteria in GF/C-filtered lake water with or without substrate enrichment or antibiotic inhibitors of cell division, or with bacterivorous protists. In lake samples, each of the staining methods detected different aspects of cellular state or metabolic activity but all 3 indicated low percentages of 'active' bacteria relative to total bacterial abundance. CTC+ ranged from 1.0 to $27.3 \%$ (average $5.1 \%$ ), NuCC from 1.4 to $42.9 \%$ (average $8.3 \%$ ) and MEM+ from 1.0 to $29.9 \%$ (average $8.8 \%$ ), with no clear seasonal or spatial patterns. No significant correlations were found between the proportions of 'active' bacteria in lake water as determined by these methods, although such correlations were observed in the laboratory experiments. Significant correlations were obtained between ETS and $\mathrm{O}_{2}$ uptake, peptidase and $\beta$-glucosidase, and between leucine incorporation and peptidase. ETS was significantly correlated with CTC+ and NuCC cell abundance, but not with total bacteria (DAPI counts). In contrast, peptidase activity correlated with total bacterial counts. Results of time course experiments indicated that some bacteria which initially appear to be inactive can become active when stimulated by substrate addition, even though cell division is inhibited. Grazing by protists increased the percentage of active bacteria, at least during the active predator-prey phase. Our data support the hypothesis that in natural waters usually only a small fraction (probably $<20 \%$ ) of the entire bacterial assemblage is strongly active metabolically at any given time. This proportion may increase dramatically with localized substrate inputs. The concept of bacterial assemblages, heterogeneous not only in terms of phylotype, but also in terms of levels of metabolic activity will need to be considered in future aquatic ecosystem models.
\end{abstract}

KEY WORDS: Metabolically active bacteria $\cdot$ Respiration $\cdot$ Hydrolytic enzymes $\cdot$ Lake Kinneret

\section{INTRODUCTION}

Recently there has been a burgeoning of interest in the topic of metabolically active as opposed to inactive bacteria in aquatic environments. This is partly due to the increased awareness of the centrality of bacterial activity in the cycling of materials and energy within

*E-mail: tberman@ocean.org.il almost all aquatic ecosystems and the realization that simply counting bacterial cells gives only very limited information concerning the role of bacteria in these systems. As a result, a variety of methodological approaches have been developed in an effort to identify the metabolically active bacteria against the background of total cell counts as usually obtained with DAPI (Porter \& Feig 1980) or Acridine Orange (Hobbie et al. 1977) staining. 
A frequently used method of appraising the fraction of metabolically active bacteria in recent years has been based on the utilization of the fluorogenic tetrazolium dye CTC. This method of identifying actively respiring bacterial cells in natural water samples was first used by Rodriguez et al. (1992). However, the ability of CTC to discriminate live, active cells from dead or inactive cells has been the subject of some debate (Ullrich et al. 1996, 1999, Choi et al. 1999, Sherr et al. 1999a). Generally, the percentages of CTC+ cells observed in marine samples have been low, usually $<5$ to $10 \%$ of total counts. Ullrich et al. $(1996,1999)$ have argued that little validity can be given to CTC results because the dye poisons bacterial metabolism. In contrast, Sherr et al. (1999a, b), inferred that CTC+ cells represent the 'very active' fraction of the total, and concluded that CTC provides a useful tool to follow metabolically active populations. For example, Smith (1998) found that the cell abundance of CTC+ was highly correlated to microplankton respiration in Chesapeake Bay. Moreover, Choi et al. (1999) showed that even the initially CTC-negative cells present in coastal seawater could become positive (CTC+) with incubation and substrate addition. Recently Sieracki et al. (1999) have shown that, for marine bacteria, CTCstained cells could be enumerated with flow cytometry with much higher sensitivity than by microscopic observation.

At least 2 other staining techniques have been proposed to identify metabolically active bacteria. Zweifel \& Hagström (1995) introduced a method based on n-propanol washing of DAPI-stained bacteria. This procedure permits visualization of nucleoid-intact as opposed to nucleoid-missing or damaged cells. Another approach has been to use a combination of 2 dyes (Syto 9 and propidium iodide, Live/Dead stain, Molecular Probes, Eugene, Oregon, USA) to distinguish between membrane intact (live) and membrane damaged (dead) cells (Choi et al. 1996, Williams et al. 1998, Gasol et al. 1999).

The principal aim of this study was to use the above approaches to estimate the proportion of the total bacterial population, as determined by direct microscope counting of DAPI-stained samples, that was live and metabolically active in Lake Kinneret, northern Israel, at different seasons and water depths. Some parameters related to microbial activity in bulk water (bacterial production and respiration, hydrolytic enzyme activities) were determined in parallel water samples. We also examined the effect of incubating Lake Kinneret water with nutrient additions on the numbers and proportions of active bacteria. In addition we experimentally evaluated the impact of protistan grazing on the relative abundance of metabolically active bacteria.

\section{MATERIALS AND METHODS}

Lake sampling program. Lake Kinneret in northern Israel is a monmictic, meso-eutrophic, relatively large lake $\left(170 \mathrm{~km}^{2}\right.$ area, $40 \mathrm{~m}$ maximum depth) with an annual, net primary productivity of $610 \mathrm{~g} \mathrm{C} \mathrm{m}^{-2} \mathrm{yr}^{-1}$ (Berman et al. 1995). Water samples were taken at almost monthly intervals from May 1997 until January 2000 at a central lake station (Stn A) from 3 depths: $1 \mathrm{~m}$ (near surface), $19 \mathrm{~m}$ (or at thermocline depth during stratification) and $38 \mathrm{~m}$ (deep hypolimnion). Samples were assayed for numbers of total and 'active' bacteria (see below) and bacterial productivity, determined by incorporation rate of radio-labeled leucine (Kirchman et al. 1985, Simon \& Azam 1989). Parallel samples were filtered through GF/C Whatman filters to remove essentially all of the phytoplankton. The filtrates were assayed for respiration rate, measured by $\mathrm{O}_{2}$ uptake in dark bottles with a high precision Winkler method and by the 'electron transport system activity' (ETS) method of Packard (1971), as modified by Kenner \& Ahmed (1975). Peptidase, $\beta$-glucosidase and lipase enzyme activities were also determined in these samples using respectively the fluorogenic substrate analogs MCA-leucine, MUF-glucose and MUF-oleate (Hoppe 1993). Chlorophyll concentrations were determined in all lake water samples by fluorometric analysis of acetone extracts (Holm-Hansen et al. 1965).

We used 3 staining procedures that purport to detect 'active' as opposed to 'total' (DAPI-stained) cells by different criteria:

(1) Staining with the water soluble fluorogenic ester, 5 cyano-2,3 ditolyl tetrazolium chloride, CTC: When reduced as a result of respiratory electron transfer, this compound yields a strongly fluorescent precipitate within microbial cells which can be detected by direct observation with epifluorescent microscopy or by flow cytometry (Sieracki et al. 1999). In this method, a $50 \mathrm{mM}$ stock solution of CTC was prepared, pretreated in a sonication bath for $1 \mathrm{~h}$ and filtered through a $0.2 \mu \mathrm{m}$ Acrodisc filter. Samples of lake water $(1 \mathrm{ml})$ were incubated with a final concentration of $5 \mathrm{mM}$ CTC (Choi et al. 1999) for $2 \mathrm{~h}$ in the dark, at ambient lake temperatures. Subsequently, the samples were fixed with a final concentration of $4 \%$ formalin and vortexed. The samples were then diluted (1:5 or 1:10), counter stained with DAPI $\left(5 \mu \mathrm{g} \mathrm{ml}{ }^{-1}\right)$ and filtered through black $0.2 \mu \mathrm{m}$ Nuclepore filters. The filters were mounted on microcope slides which were stored at $-10^{\circ} \mathrm{C}$, and subsequently thawed and examined within $24 \mathrm{~h}$. Total bacterial cells were counted at $1250 \times$ magnification by DAPI blue fluorescence (Zeiss \#4877-02) and then with green excitation (Zeiss \#487715) for red fluorescing (i.e., highly ETS-active) CTC+ cells (Choi et al. 1999). 
(2) DAPI staining followed by propanol wash: This method, which was introduced by Zweifel \& Hagström (1995), may distinguish between bacterial cells with intact nucleoids, NuCC (which presumably retain their metabolic integrity), and non-NuCC cells (which are presumed to be inactive).

We slightly modified the procedure of Zweifel \& Hagström (1995) and Choi et al. (1996). Lake water samples were fixed with $4 \%$ (final concentration) borate buffered formalin and diluted 1:10 or 1:5 before staining. A $5 \mathrm{ml}$ portion of diluted sample was incubated with $0.5 \mathrm{ml}$ of DAPI (final concentration $10 \mu \mathrm{g}$ $\mathrm{ml}^{-1}$ ) in the dark for $5 \mathrm{~min}$ and then filtered onto a $0.2 \mu \mathrm{m}$ black Nuclepore filter. The organisms on the filter were washed 5 times with $1 \mathrm{ml}$ warm $\left(70\right.$ to $80^{\circ} \mathrm{C}$ ) iso-propanol. The filter was then mounted on a microscope slide and the bacteria were observed immediately by DAPI fluorescence. Cells with yellow staining interiors were counted as NuCC positive or 'active' cells.

(3) Live/Dead staining: The Syto 9/propidium iodide Live/Dead stain (Molecular Probes) differentiates between bacterial cells with or without intact cell membranes. In this method, all cells are stained with the green-fluorescing Syto 9 stain, but only cells with compromised, or damaged, membranes permit the passage of the red fluorescing stain, propidium iodide, into the cell.

The Live/Dead stain was prepared by mixing equal volumes of Stain A and Stain B. Suitably diluted (1:5 or 1:10) samples of lake water were fixed with $4 \%$ glutaraldehyde and $5 \mathrm{ml}$ of $0.1 \mathrm{M}$ carbonate buffer, $\mathrm{pH} 9$. A $3 \mu \mathrm{l}$ portion of the mixed stains $\mathrm{A}+\mathrm{B}$ was added, and after 10 min incubation in the dark the sample was drawn through the filter. The filter was mounted on a small drop of water on a microscope slide, and a drop of Molecular Probes Mounting Oil was placed on top of the filter, which was then sealed with a cover slip. The cells were viewed immediately under epifluorescence (Zeiss \#487714 and \#487702 ). Red cells were counted as membrane compromised, or 'dead', cells (MEM-), while green fluorescing cells were counted as 'live' or 'active', i.e., membrane intact (MEM+).

All microscope observations were made at $1250 \times$ magnification with a Zeiss Axiomat microscope equipped with a $100 \mathrm{~W}$ mercury bulb and a Zeiss Attoarc controller. At least 10 random fields were counted for all samples. In order to examine possible inter-relationships between measured parameters (bacterial numbers, proportions of active bacteria, metabolic determinants), discrete, single pair simple regression analysis was made using GBstat 6.5 software (Dynamic Microsystems Inc.).

Laboratory experiments. In order to assess the potential impact of nutrient additions on the propor- tions of active bacteria we ran a series of 9 laboratory experiments using lake water amended with phosphorus (as $\mathrm{KH}_{2} \mathrm{PO}_{4}$ ), nitrogen (as $\mathrm{NaNO}_{3}$ and $\mathrm{NH}_{4} \mathrm{Cl}$ ) or an organic supplement (Difco tryptose, a hydrolyzed protein digest). In some runs, we also checked the effect of adding a mixture of trace metal ions.

Nutrient addition experiments: Water samples taken from $1 \mathrm{~m}$ depth at a pelagic lake station were passed through GF/C filters to remove most of the larger organisms and particulates leaving essentially bacteria and viruses in the filtrate. Portions $(600 \mathrm{ml})$ of the filtrate were distributed into duplicate $1 \mathrm{l}$ flasks and incubated in the dark at near ambient lake temperatures ranging from 20 to $28^{\circ} \mathrm{C}$. Additions were made to separate flasks as follows: (1) nitrogen, $100 \mu \mathrm{M}$ (as $50 \mu \mathrm{M}$ $\mathrm{NH}_{4} \mathrm{Cl}$ and $\left.50 \mu \mathrm{M} \mathrm{NaNO}\right)_{3}$; (2) phosphorus, $10 \mu \mathrm{M}$ (as $\mathrm{KH}_{2} \mathrm{PO}_{4}$ ); (3) nitrogen + phosphorus (1 plus 2); (4) Difco tryptose protein hydrolysate, $0.02 \%$; (5) glucose, $0.02 \%$; (6) trace metals $(0.2 \mu \mathrm{M} \mathrm{Zn}, 0.4 \mu \mathrm{M} \mathrm{Fe}, 0.2$ $\mu \mathrm{M}$ Mo, $0.05 \mu \mathrm{M}$ Mn, $0.04 \mu \mathrm{M}$ Co); (7) phosphorus + trace metals (2 plus 6); (8) nitrogen + trace metals (3 plus 6). These concentrations of supplements were made to ensure nutrient sufficiency for bacterial outgrowth and are between 5- and 10-fold the maximum concentrations found in the lake. Control flasks received no additions.

Time course experiments: Another series of 8 experiments was run with GF/C-filtered lake water to follow the changes in the percentage of active bacteria over time after sampling with or without addition of tryptose as a growth factor. In the time course experiments made after June 1998 we also added a parallel series of flasks supplemented with an antibiotic mixture (naladixic acid, promidic acid and piperidic acid; Kogure et al. 1987) in order to stop cell replication but not overall metabolism (Choi et al. 1999). Samples were withdrawn from the flasks immediately at the start of the incubations and at various times subsequently (for time course experiments) or after $24 \mathrm{~h}$ (for nutrient addition experiments). These samples were then analyzed for live and metabolically active bacteria (CTC, NuCC and Live/Dead staining methods). In most of the nutrient addition and time course experiments, ETS, $\mathrm{O}_{2}$ respiration and radioactive leucine incorporation were also measured in parallel.

Impact of flagellate or ciliate grazing on proportion of active bacteria: A mixture of small heterotrophic flagellates (mainly Bodo sp.) or, in one case, a monoculture of ciliates (Colpoda) previously grown on a mineral medium with added bacteria, was washed on a $1 \mu \mathrm{m}$ screen with 5 portions of $0.2 \mu \mathrm{m}$ filtered lake water and then resuspended in $0.2 \mu \mathrm{m}$ GF/C-filtered lake water. In 3 out of 4 experiments, parallel treatments with $0.02 \%$ tryptose addition were also prepared. The treatments were incubated in the labora- 
tory at ambient lake temperatures in the dark for 3 or 4 $\mathrm{d}$ and the proportions of CTC+, NuCC or MEM+ in the total (DAPI) bacterial population were monitored daily.

\section{RESULTS}

\section{Lake sampling program}

In Fig. 1 we show the concentrations of chlorophyll and the total bacterial counts determined with DAPI staining in the near surface waters (1 m depth) from May 1997 through January 2000. Near surface chlorophyll concentrations ranged from $148 \mu \mathrm{g} \mathrm{l}^{-1}$ (during a Peridinium bloom) to $5.4 \mathrm{\mu g} \mathrm{l}^{-1}$, bacterial abundance varied from $1.3 \times 10^{7}$ to $2.2 \times 10^{6}$ cells ml $^{-1}$. Although in some cases the total bacterial counts appeared to increase and decrease in tandem, or after a slight lag, with the chlorophyll concentrations (e.g., March-May 1998; May 1999), there was no significant correlation between these parameters. Total bacterial abundance at other depths was essentially similar to that at $1 \mathrm{~m}$ and followed the same general seasonal pattern (data not shown).

In samples from the lake profiles, all 3 staining methods used to determine metabolically active bacteria gave low apparent levels of 'live and active' compared to 'inactive' cells (Table 1). Generally, the lowest percentage of 'active' cells was recorded with the CTC assay. No clear seasonal pattern of elevated or depressed percentages of CTC+, NuCC or MEM+ cells was observed from mid-1997 through January 2000, although there was some tendency toward higher proportions of $\mathrm{CTC}+$ during late autumn and winter

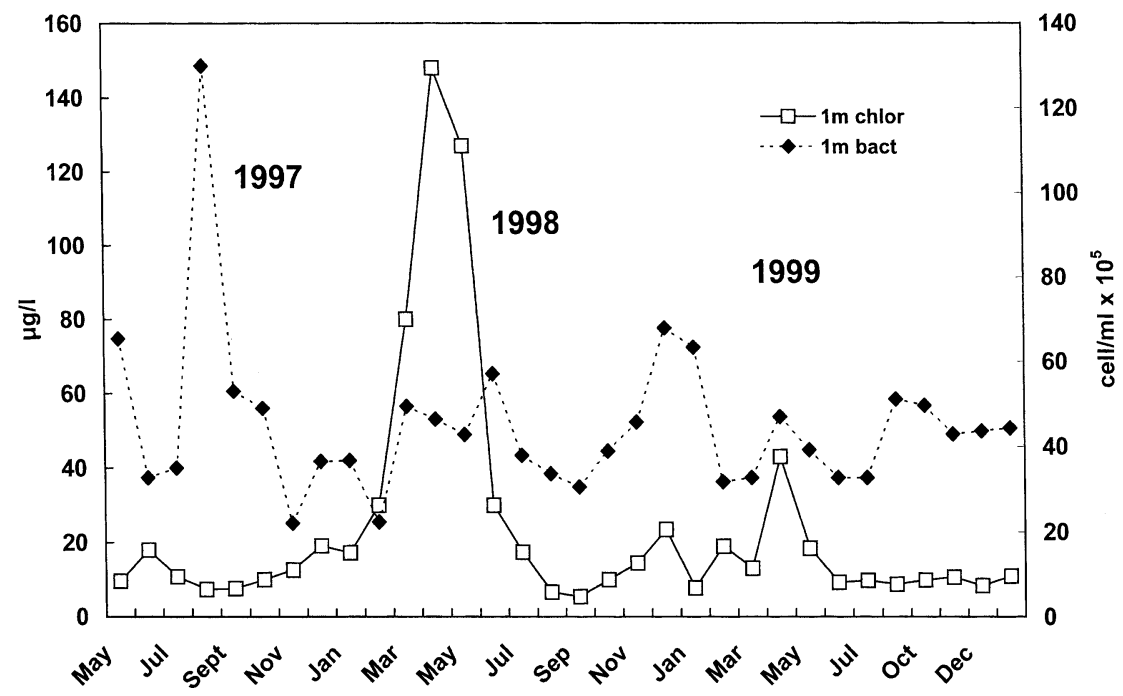

Fig. 1. Total bacteria (DAPI counts, cells $\mathrm{ml}^{-1}$ ) and chlorophyll ( $\mu$ g chlorophyll $\mathrm{l}^{-1}$ ) at $1 \mathrm{~m}$ depth at a pelagic station (Stn A) in Lake Kinneret, northern Israel months in samples from $38 \mathrm{~m}$ (Fig. 2). Contrary to expectation, direct comparison of the proportions of 'active' bacteria, determined in the same lake water samples, did not show any significant correlations between the 3 different methods. This was found both for the entire data set from lake profiles and for data from each of the 3 sampled depths $(0,19$ and $38 \mathrm{~m})$ taken separately.

Six other independent parameters related to potential microbial activity were determined in lake water samples: rate of leucine incorporation (a measure of bacterial productivity), ETS and $\mathrm{O}_{2}$ uptake (indicators of respiratory activity) and the enzymatic activities of peptidase, $\beta$-glucosidase and lipase. Single pair regression analysis showed that the rates of leucine incorporation were significantly positively related to both the ambient concentrations of chlorophyll and photosynthetic carbon fixation rates (Table 2). Significant correlations were also found between leucine uptake and peptidase (but not $\beta$-glucosidase or lipase) activity, between ETS and $\mathrm{O}_{2}$ uptake, between ETS and peptidase and between ETS and $\beta$-glucosidase (Table 2). No correlations were observed between ETS and leucine incorporation.

Of the 3 measured enzyme activities, $\beta$-glucosidase activity was consistently higher than peptidase activity; while lipase activity was always the lowest, based on molar rates of substrate hydrolysis (Table 3 ). Generally hydrolytic enzyme activity decreased with depth, although occasionally maximum activities were found in thermocline samples when the lake was strongly stratified (data not shown). No significant correlations were found between these 3 enzyme activities.

We regressed the levels of metabolic activities (ETS activity, radioactive leucine incorporation and peptidase activity) to the numbers of total (DAPI) counts or 'active' (CTC+, $\mathrm{NuCC}$ or $\mathrm{MEM}+$ ) cells. ETS activity was significantly directly correlated to the numbers of CTC+ and NuCC cells (albeit with low correlation coefficients) but not to total bacterial counts (Table 4). Leucine incorporation rates showed no correlation to either total or 'active' bacterial numbers. Surprisingly, we found that peptidase activity from 1 and $19 \mathrm{~m}$ depths was significantly directly correlated to total (DAPI-stained) bacterial counts but not to the numbers of CTC+, $\mathrm{NuCC}$ or MEM+ cells. No relationships were observed between any of the activity parameters and numbers of MEM+ bacteria. 
Table 1. Lake Kinneret. Percentages of 'active' bacteria (CTC+, NuCC, MEM+) relative to total bacterial cells (DAPI counts). Summary of data for lake samples January 2000. Standard deviations in parentheses

\begin{tabular}{|c|c|c|c|c|c|c|c|c|c|}
\hline \multirow{2}{*}{$\begin{array}{l}\text { Depth } \\
\text { (m) }\end{array}$} & \multicolumn{3}{|c|}{ CTC+ } & \multicolumn{3}{|c|}{$\mathrm{NuCC}$} & \multicolumn{3}{|c|}{ MEM+ } \\
\hline & Avg. & Max. & Min & Avg. & Max & Min & Avg & Max. & Min. \\
\hline 1 & $4.1( \pm 3.3)$ & 12.8 & 1.0 & $7.2( \pm 7.3)$ & 41.1 & 1.8 & $7.6( \pm 4.6)$ & 20.5 & 1.6 \\
\hline 19 & $4.7( \pm 3.3)$ & 13.3 & 1.0 & $8.0( \pm 7.7)$ & 42.9 & 1.4 & $9.9( \pm 6.1)$ & 21.9 & 1.9 \\
\hline 38 & $6.5( \pm 6.3)$ & 27.3 & 1.0 & $9.7( \pm 6.5)$ & 29.8 & 1.4 & $8.8( \pm 3.1)$ & 14.5 & 1.0 \\
\hline
\end{tabular}
from May 1997 (CTC+), October 1997 (NuCC) and May 1998 (MEM+) until

\section{Laboratory experiments}

Similarly to the determinations in the lake water samples, the initial percentages of 'active' bacteria as detected by all 3 methods in the laboratory experiments were low, generally $<10 \%$. However, in contrast to our observations in lake samples, we found a very significant correlation between the percentage of CTC+ and $\mathrm{NuCC}$ cells in both the time course

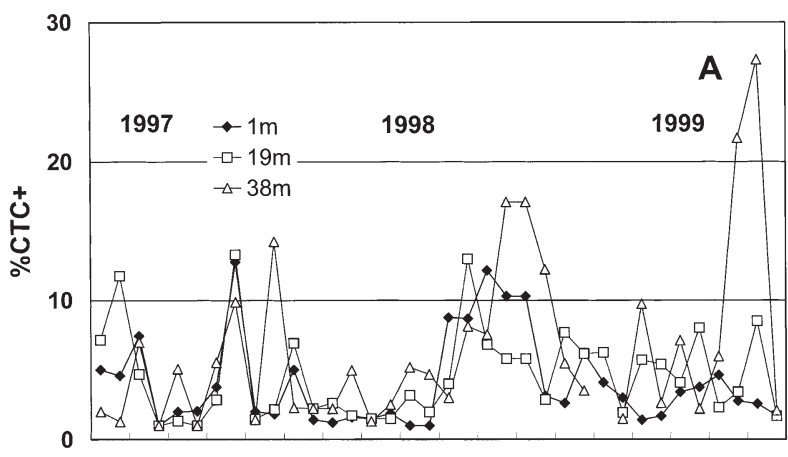

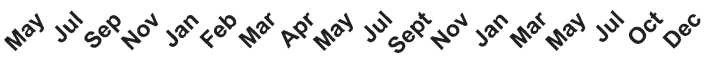
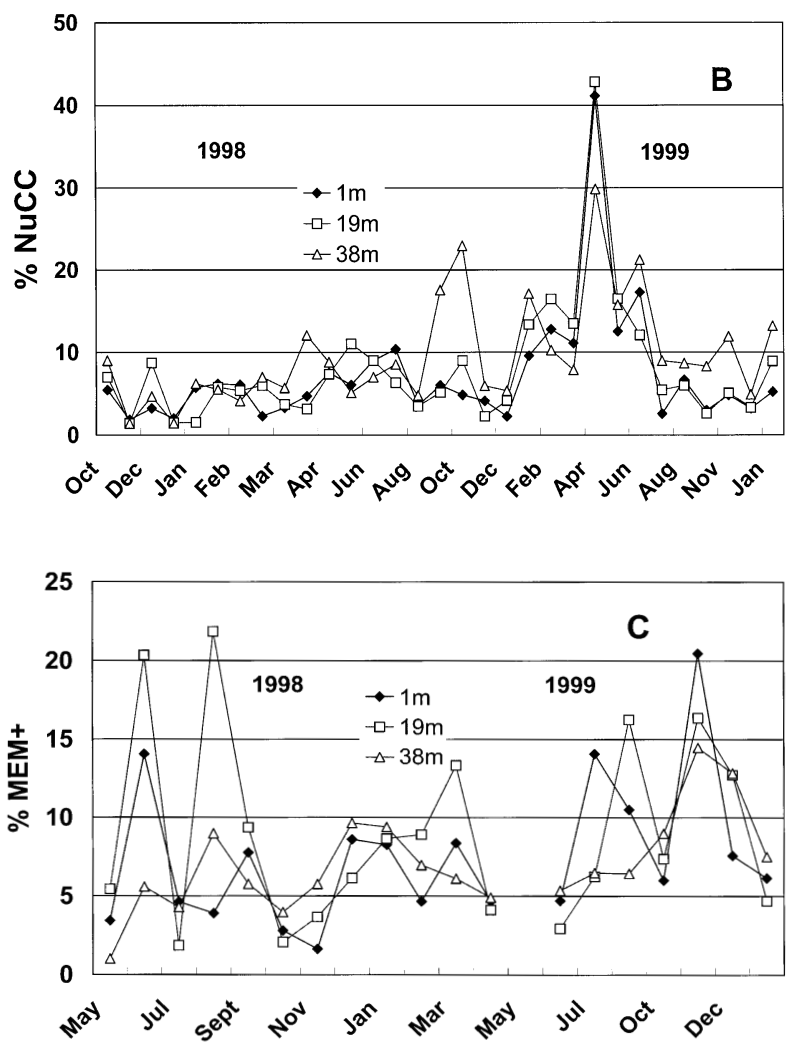

Fig. 2. Lake Kinneret. Percentages of (A) CTC+; (B) NuCC; and (C) MEM+ bacteria; samples taken at Stn A from 3 depths $(1 \mathrm{~m}, 19 \mathrm{~m}$ or thermocline, and $38 \mathrm{~m})$ and the nutrient addition experiments (Table 5). Somewhat weaker, but still significant, correlations were $\mathrm{MEM}+$ cells and between CTC+ and MEM+ (Table 5). We note, however, that the Live/Dead staining method often gave highly variable results in many of the time course and nutrient addition experiments.

Table 2. Lake Kinneret samples. Relationships between paraleucine incorporation rate, peptidase and $\beta$-glucosidase activity. Also shown are the relationships between leucine incorporation rate, chlorophyll and primary production

\begin{tabular}{|c|c|c|c|c|}
\hline$y$ & $x$ & $r^{2}$ & $\mathrm{p}$ & $\mathrm{n}$ \\
\hline ETS & Leucine & - & \multicolumn{2}{|l|}{ No correlation } \\
\hline ETS $^{a}$ & Peptidase & 0.54 & $<0.0001$ & 42 \\
\hline $\mathrm{ETS}^{\mathrm{b}}$ & Peptidase & 0.38 & $<0.0001$ & 63 \\
\hline $\mathrm{ETS}^{\mathrm{a}}$ & $\Delta \mathrm{O}_{2}$ & 0.15 & 0.01 & 45 \\
\hline ETS $^{a}$ & $\beta$-glucosidase & 0.23 & 0.0044 & 32 \\
\hline ETS $^{b}$ & $\beta$-glucosidase & 0.11 & 0.015 & 48 \\
\hline Leucine $^{a}$ & Peptidase & 0.19 & $<0.007$ & 36 \\
\hline Leucine $^{\mathrm{b}}$ & Peptidase & 0.25 & $<0.0001$ & 54 \\
\hline Leucine $^{c}$ & Chlorophyll & 0.61 & $<0.0001$ & 22 \\
\hline Leucine $^{\mathrm{c}}$ & Primary prod. & 0.33 & 0.0044 & 22 \\
\hline \multicolumn{5}{|c|}{ 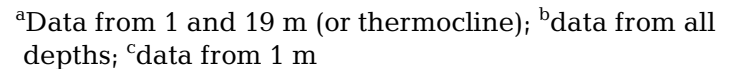 } \\
\hline
\end{tabular}

Table 3. Hydrolytic enzyme activities in Lake Kinneret. Activities given as $\mu \mathrm{mol}^{-1} \mathrm{~h}^{-1}$ of substrate hydrolyzed

\begin{tabular}{|llll|}
\hline Depth $(\mathrm{m})$ & Mean & SD & $\mathrm{n}$ \\
\hline Peptidase & & & \\
1 & 0.44 & 0.40 & 24 \\
19 & 0.24 & 0.08 & 24 \\
38 & 0.17 & 0.06 & 24 \\
Lipase & & & \\
1 & 0.11 & 0.17 & 9 \\
19 & 0.10 & 0.16 & 9 \\
38 & 0.06 & 0.09 & 9 \\
$\beta$-glucosidase & & & \\
1 & 2.17 & 5.3 & 21 \\
19 & 1.60 & 4.6 & 21 \\
38 & 0.49 & 0.38 & 21 \\
\hline
\end{tabular}
also found between the percentages of NuCC and meters of bacterial activity: ETS, oxygen consumption, 
Table 4. Lake Kinneret. Correlations between metabolic activity parameters and numbers of total (DAPI) or 'active' (CTC+ or NuCC) bacteria. No correlations were found between activity parameters and numbers of MEM+ cells. Data refer to direct regressions

\begin{tabular}{|lccrr|}
\hline Parameter & Bacteria & $\mathrm{r}^{2}$ & $\mathrm{p}$ & $\mathrm{n}$ \\
\hline ETS & CTC+ & 0.15 & 0.0003 & 88 \\
ETS & NuCC & 0.16 & 0.0007 & 68 \\
Peptidase & DAPI & 0.23 & $<0.0001$ & 66 \\
\hline
\end{tabular}

Table 5. Laboratory experiments. Relationships between percentages of CTC+, NuCC and MEM+ cells

\begin{tabular}{|lccc|}
\hline Parameters & $\mathrm{r}^{2}$ & $\mathrm{p}$ & No. of samples \\
\hline CTC+ and NuCC & 0.53 & $<0.0001$ & 181 \\
CTC+ and MEM+ & 0.12 & $<0.0001$ & 165 \\
NuCC and MEM+ & 0.16 & $<0.0001$ & 156 \\
\hline
\end{tabular}

\section{Time course experiments}

In preliminary experiments (not shown) we found that there were no significant changes in the proportions of CTC+, NuCC or MEM+ cells to total bacterial numbers, even with the addition of tryptose or other nutrients with incubation times of less than 10 to $12 \mathrm{~h}$, at temperatures ranging from 20 to $25^{\circ} \mathrm{C}$. Unsupplemented, GF/C-filtered lake water samples showed a trend to higher DAPI bacterial counts and relative proportions of active bacteria (ranging from 1.5- to 5-fold, in 5 out of 7 time course experiments) after 20 to $24 \mathrm{~h}$. Not surprisingly, when tryptose was added, much greater increases were observed in both the total and 'active' cell counts as measured by all 3 staining methods. The incorporation rate of radioactive leucine was similarly stimulated by tryptose. In the presence of the antibiotic cocktail, the increase in bacterial abundance (DAPI) and rates of leucine incorporation were considerably inhibited even with tryptose addition after $22 \mathrm{~h}$ (Fig. 3). However, for 2 experiments in which incubations were continued until $40 \mathrm{~h}$, we found greatly increased percentages of $\mathrm{CTC}+$ and $\mathrm{NuCC}$, but only a moderate increase in DAPI counts in the tryptose plus antibiotics treatments by the end of the incubation. In Table 6 we detail the increases relative to time zero in total bacterial cell counts, leucine uptake and the percentages of CTC+ and NuCC after 22 and $40 \mathrm{~h}$ incubation with or without added tryptose and/or the antibiotic mixture (experiment of 6 December 1999). Addition of tryptose alone gave large increases in all parameters tested except DAPI (only 3.7-fold increase) within $22 \mathrm{~h}$ (Table 6). By $40 \mathrm{~h}$, the 'antibiotic only'
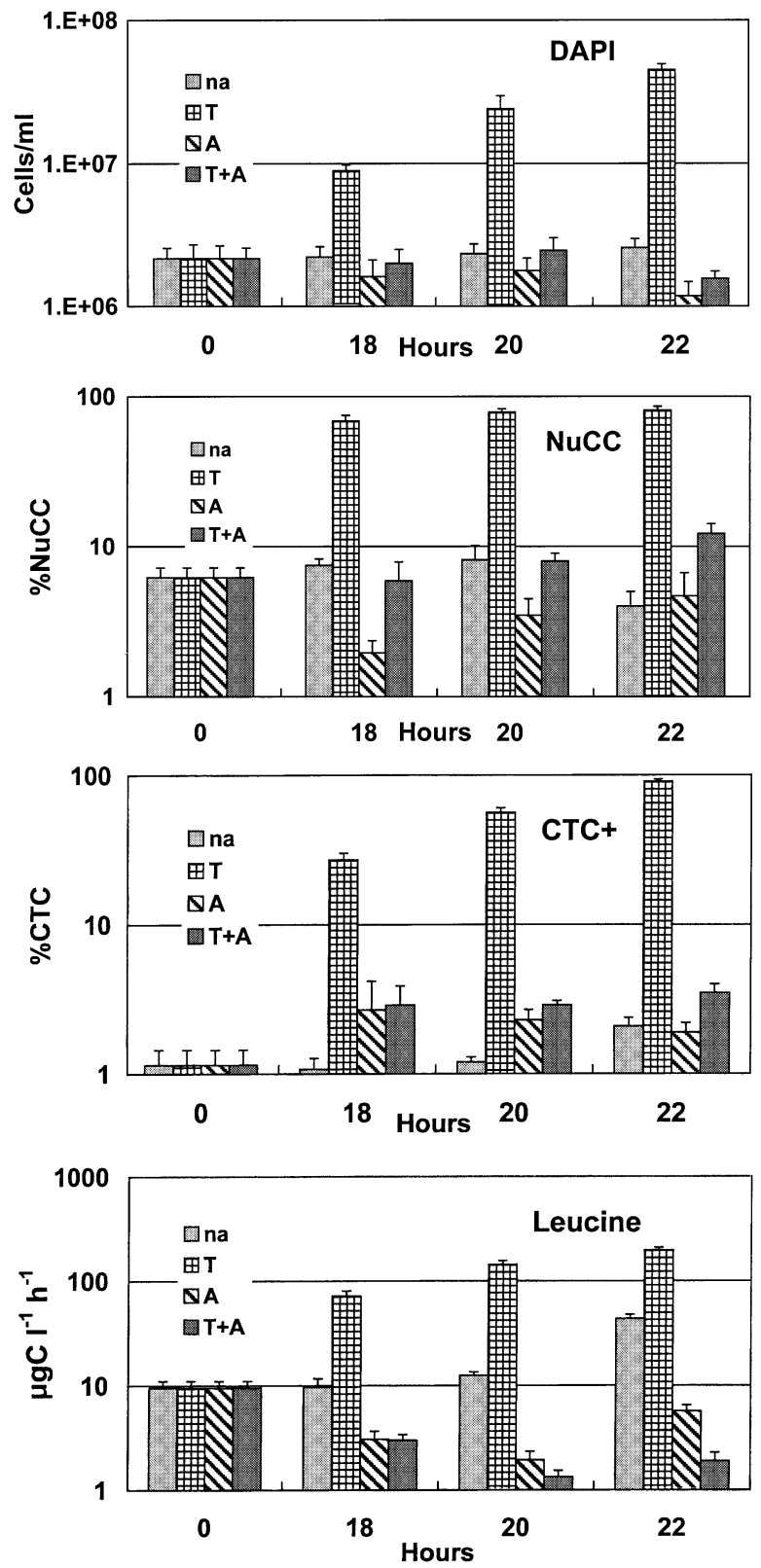

Fig. 3. Time course experiment (6 December 1999). Change in total bacterial abundance (DAPI, cells $\mathrm{ml}^{-1}$ ), rate of leucine incorporation $\left(\mu \mathrm{g} \mathrm{C}^{-1} \mathrm{~h}^{-1}\right.$ ) and the percentage of CTC+ and NuCC cells with time of incubation of GF/C-filtered Lake Kinneret water. (Note logarithmic scale on $y$-axis). Treatments: $\mathrm{na}=$ no addition, $\mathrm{T}=$ tryptose $(0.02 \%), \mathrm{A}=$ antibiotic cocktail (see 'Materials and methods'), $\mathrm{T}+\mathrm{A}=$ tryptose + antibiotics. (Average of duplicate samples, error bars indicate standard deviation of all counts made in both samples)

treatment also showed 3- to 6-fold rises in all parameters, the relative increases in $\mathrm{CTC}+, \mathrm{NuCC}$ and leucine uptake being about twice that for DAPI counts. Combined addition of antibiotics and tryptose led to much greater increases in the percentages of CTC+ and NuCC, but not in DAPI counts or leucine uptake. 
Table 6. Time course experiments, December 1988. Relative increase in total bacterial cell counts and activity parameters with or without added tryptose and/or antibiotic mix. NA = no addition; $\mathrm{T}=0.02 \%$ tryptose; $\mathrm{A}=$ antibiotics (see 'Materials and methods'); DAPI = total bacterial cell counts; Leucine = leucine uptake. Parameter increases are shown normalized to their initial (time 0) levels in each treatment taken as 1

\begin{tabular}{|lcccr|}
\hline Hour & NA & T & A & T+A \\
\hline DAPI & & & & \\
22 & 1.7 & 3.7 & 1.9 & 1.0 \\
40 & 4.4 & 52.3 & 3.1 & 3.6 \\
Leucine & & & & \\
22 & 5.6 & 19.1 & 1.8 & 2.5 \\
40 & 5.9 & 24.3 & 6.3 & 6.3 \\
CTC+ & & & & \\
22 & 3.5 & 24.3 & 1.1 & 4.3 \\
40 & 2.4 & 46.3 & 6.5 & 22.2 \\
NuCC & & & & \\
22 & 2.2 & 7.9 & 3.8 & 2.8 \\
40 & 5.6 & 31.4 & 6.0 & 25.7 \\
\hline
\end{tabular}

\section{Nutrient addition experiments}

This set of experiments was intended to examine whether various nutrient supplements to GF/C-filtered lake water, followed by $24 \mathrm{~h}$ incubation, would affect the proportion of $\mathrm{CTC}+, \mathrm{NuCC}$ or MEM+ bacteria or ETS activity. A summary of the results of 9 experiments is shown in Table 7.

The Syto-9 Live/Dead method gave poor results in this series, and in 6 out of 9 experiments showed no consistent pattern in any of the treatments. In contrast, CTC and NuCC methods showed similar responses, at

Table 7. Response of Lake Kinneret bacteria to nutrient additions as measured by relative increase of active cells in the total population or ETS activity after $24 \mathrm{~h}$ incubations. Added nutrient code: $\mathrm{T}=$ tryptose $(0.02 \%) ; \mathrm{G}=$ glucose $(0.02 \%) ; \mathrm{N}=$ nitrogen $\left(100 \mu \mathrm{M}\right.$ as $\left.\mathrm{KNO}_{3}+\mathrm{NH}_{4} \mathrm{Cl}\right) ; \mathrm{P}=$ phosphorus $(10 \mu \mathrm{M}$ as $\mathrm{KH}_{2} \mathrm{PO}_{4}$ ); $\mathrm{M}=$ trace metals (see 'Materials and methods'). NA = no addition; $\mathrm{nr}=$ no response. Bold letters indicate an increase of $>10$-fold and normal font indicates an increase of $>3$-fold from time zero respectively

\begin{tabular}{|c|c|c|c|c|}
\hline \multirow[t]{2}{*}{ Date } & \multicolumn{4}{|c|}{ Detection criterion } \\
\hline & $\mathrm{CTC}+$ & $\mathrm{NuCC}$ & MEM+ & ETS \\
\hline Mar 1998 & $\mathbf{T}, \mathrm{N}, \mathrm{P}, \mathrm{N}+\mathrm{P}, \mathrm{M}$ & $T, N, P, N+P, M$ & $\mathrm{nr}$ & $\mathrm{T}$ \\
\hline Apr 1998 & $\mathrm{~T}, \mathrm{G}$ & $\mathrm{T}$ & $\mathrm{nr}$ & $\mathrm{T}$ \\
\hline Aug 1998 & $\mathrm{~T}, \mathrm{~N}, \mathrm{P}, \mathrm{N}+\mathrm{P}, \mathrm{M}$ & $\mathbf{T}, \mathbf{N}, \mathrm{P}, \mathrm{N}+\mathrm{P}, \mathrm{M}$ & $\mathrm{nr}$ & $\mathrm{T}$ \\
\hline Nov $1998^{a}$ & $\mathbf{T}$ & $\mathbf{T}$ & $\mathrm{T}, \mathrm{G}$ & $\mathrm{nr}$ \\
\hline Jan $1999^{a}$ & $\mathrm{~T}$ & $\mathrm{~T}, \mathrm{~N}+\mathrm{P}$ & $\mathrm{N}$ & $\mathrm{nr}$ \\
\hline Mar 1999a & $T, P, N+P$ & $\mathrm{~T}$ & $\mathrm{nr}$ & $\mathrm{T}, \mathrm{G}$ \\
\hline Jun 1999 & $T, N, P, N A$ & $\mathrm{~T}$ & $\mathrm{nr}$ & $\mathrm{T}$ \\
\hline Sep 1999 & $\mathrm{nr}$ & $\mathrm{T}$ & $\mathrm{nr}$ & $\mathrm{T}, \mathrm{P}$ \\
\hline Dec 1999 & $\mathbf{T}, \mathrm{G}, \mathrm{P}, \mathrm{N}+\mathrm{P}, \mathrm{M}, \mathbf{N A}$ & $\mathrm{T}, \mathrm{G}, \mathrm{N}, \mathrm{P}, \mathrm{N}+\mathrm{P}$ & $\mathrm{T}, \mathrm{G}, \mathrm{P}, \mathrm{N}+\mathrm{P}, \mathrm{M}$ & $\mathrm{T}, \mathrm{G}$ \\
\hline
\end{tabular}

least qualitatively, in most experiments. Tryptose additions in all experiments (with the exception of CTC in September 1999) caused an increase both in total bacterial counts and in the proportion of $\mathrm{CTC}+$ and $\mathrm{NuCC}$ cells. In about half of the experiments, relative increases in the proportions of 'active' cells were observed with additions of either nitrogen or phosphorus or both. Supplements of trace metals alone also occasionally increased the percentages of CTC+ and NuCC cells. Glucose, generally considered a very effective carbon and energy source for bacteria, only rarely stimulated the appearance of active cells. ETS activity usually increased with tryptose addition, and occasionally with added glucose or P (Table 7).

\section{Impact of flagellate or ciliate grazing on proportion of active bacteria}

Four experiments were made to examine the effect on percentages of active bacteria of adding an inoculum of heterotrophic flagellates (mostly Bodo sp.) or, in one experiment, ciliates (Colpoda sp.) to samples of GF/C-filtered lake water. In tests with unsupplemented lake water, we consistently observed higher levels of $\mathrm{CTC}+, \mathrm{NuCC}$ or MEM+ cells within the total bacterial populations in the samples with added protists after the first day's incubation (Fig. 4). This higher proportion of active cells was generally, but not always, maintained during the rest of the incubation. Similarly to previous experiments (see above) higher proportions of active bacteria were always found in samples with added tryptose in comparison with unsupplemented samples (Fig. 4B to D). When both tryptose and flagellates were added, higher levels of active bacteria than in tryptose-only treatments were observed after $24 \mathrm{~h}$, with some subsequent decline (Fig. 4B,D). In the single experiment with Colpoda sp., the \% of CTC+ cells with tryptose and ciliate addition only became greater than the tryptose-only sample by Day 3 (Fig. 4C).

\section{DISCUSSION}

\section{Proportion of 'active' to 'non-active' bacteria}

Many previous studies in both marine and freshwater environments, using a variety of staining approaches have reported low percentages of 'metabolically active' compared to to- 

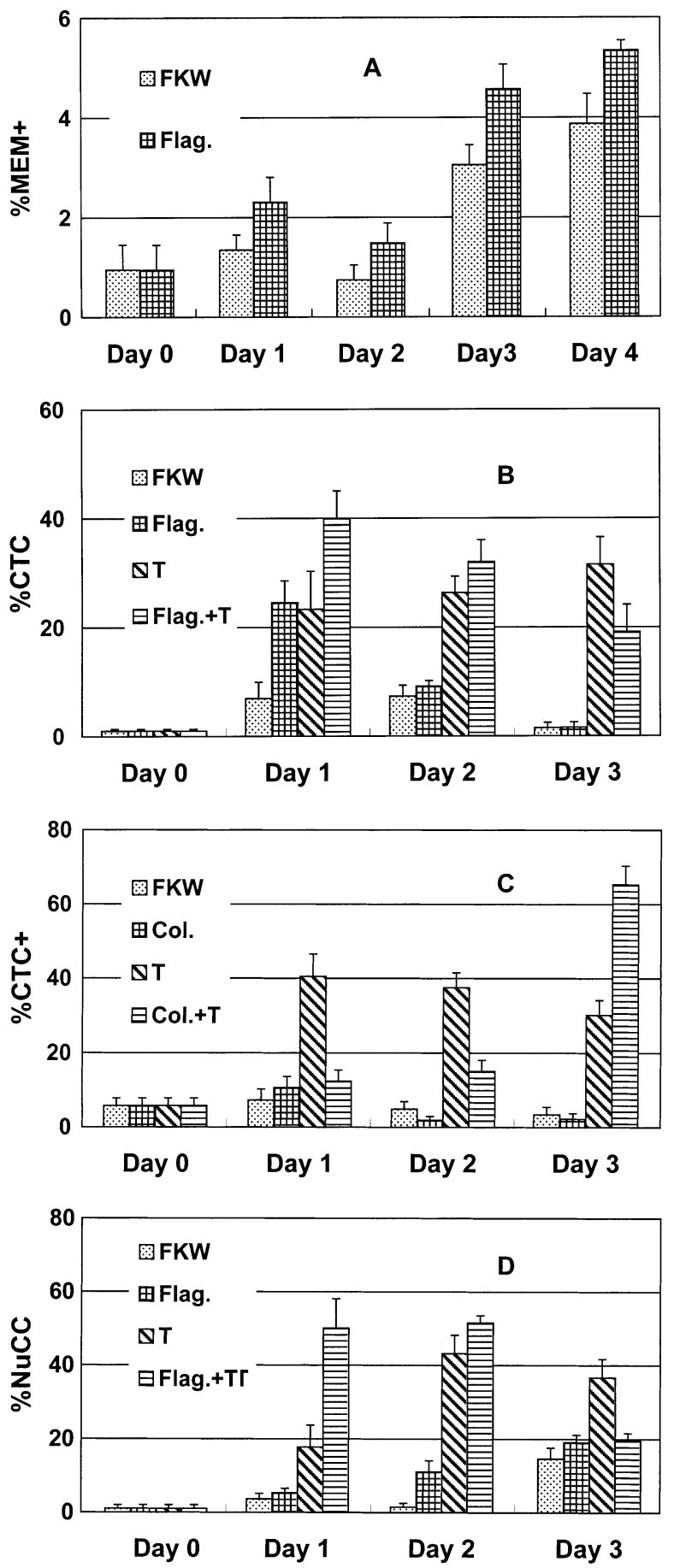

Fig. 4. Changes with incubation time of GF/C-filtered Lake Kinneret water, with or without added protists, on the percentages of $\mathrm{CTC}+, \mathrm{NuCC}$ or MEM+ cells in total (DAPI) bacterial populations. Treatments: $\mathrm{FKW}=\mathrm{GF} / \mathrm{C}$-filtered Lake Kinneret water, $\mathrm{T}=$ Lake Kinneret water $+0.02 \%$ tryptose, Prot $=$ Lake Kinneret water + protists (flagellates or Colpoda sp. as indicated), Prot $+\mathrm{T}=$ Lake Kinneret water + protists + $0.02 \%$ tryptose. (Average of duplicate samples, error bars indicate standard deviation of all counts made in both samples). Dates of experiments as follows: (A) 5 April 1998,

(B) 12 March 2000, (C, D) 26 June 2000 tal bacteria. For example, Porter et al. (1995) found that $93 \%$ of cells in oligotrophic lake water did not appear to be viable as indicated by the integrity of their membranes. With CTC, the proportion of bacteria in most natural environments showing respiratory activity has usually been <10\% (del Giorgio \& Scarborough 1995, Choi et al. 1996, Karner \& Fuhrman 1997, Choi et al. 1999). Bernard et al. (2000) in an elegant study comparing the diversity of an entire bacterial assemblage with that of the actively respiring fraction and of culturable bacteria in Mediterranean coastal waters also reported that only $3 \%$ of the total bacteria were CTC+. Choi et al. (1996), using the Molecular Probes Live/Dead kit, found that 78 to $93 \%$ of cells in samples collected in Oregon coastal seawater in late summer were membrane-damaged. With their DAPI n-propanol wash method, Zweifel \& Hagström (1995) observed that from 68 to $98 \%$ of coastal bacterioplankton did not appear to have DNA organized in a nucleoid region. Heissenberger et al. (1996) found that in a marine, free-living bacterial community, $34 \%$ of cells appeared to be intact, $42 \%$ exhibited damaged cell wall and membranes, and $24 \%$ of cells appeared to lack any internal structure. There are, however, also reports of higher proportions of active bacteria. Del Giorgio et al. (1997), using Molecular Probes stains Syto-13 and Topro-1 for flow cytometric detection of total bacteria and membrane-damaged bacteria respectively, reported that only 10 to $15 \%$ of cells appeared to be damaged in the epilimnetic waters of a number of lakes. Nevertheless, in most aquatic environments, usually a small fraction of the total bacterial population appears to be active by the above criteria at any given time. The present study corroborates these previous findings, in that there were low proportions of active relative to non-active bacteria in samples from Lake Kinneret taken at all seasons and at 3 depths in the pelagic water column (Table 1, Fig. 2). This was observed with 3 independent staining methods that measure different aspects of cellular activity or integrity.

We note, however, that much higher levels of 'active' bacteria have been observed with other techniques. For example, Grossart \& Azam (pers. comm.) have noted higher percentages of motile bacteria than CTC+ cells in the same samples. Using autoradiography, Ouverney \& Fuhrman (1999) found that a high proportion of the total bacterial population at 2 coastal sites in southern California incorporated radioactive substrates and Karner \& Fuhrman (1997) observed much higher percentages of cells which took up radioactive amino acids than CTC+. Motilty and substrate uptake are undoubtedly attributes of metabolically active cells but may actually require only low levels of energy expenditure. The relative proportions of bacteria showing various characteristics of activity to 
the total bacterial assemblage (e.g., as determined by DAPI) will certainly be different depending on environmental conditions (temperature, substrate availability, etc.) and sample source. Since bacteria in aquatic environments show a wide range of metabolic activity states, from highly to very weakly active, to dormant (i.e., capable of reactivation under suitable conditions) or dead (i.e., with no hope of resurrection), there is unlikely to be any single criterion that can be used to characterize unequivocally live or metabolically active bacteria.

Although all 3 of the methods that we used to assess 'active' bacteria in samples taken directly from the lake gave consistently low values, no significant correlations were found between these techniques. However, this was not the case when comparisons were made between the results of the 3 methods obtained with laboratory experiments, which entailed relatively long incubations (20 to $40 \mathrm{~h}$ ). In these experiments, much higher percentages of 'active' bacteria were observed with all 3 methods, evidently due to bacterial outgrowth during the incubations after a lag of some 10 to $12 \mathrm{~h}$. This wider spread of percentages of active bacteria led to significant linear relationships between the methods (Table 5).

The results of this study support the suggestion by Sherr et al. (1999b) that CTC staining based on a protocol of short ( 2 to $3 \mathrm{~h}$ ) incubations with $5 \mu \mathrm{M} \mathrm{CTC}$ detects only the most highly active of the 'metabolically active' or living cells (in this case, active in terms of their electron transfer system). Nevertheless, as these authors have pointed out, the CTC method can be useful to gain some idea of the levels of highly active bacteria within natural populations and to follow changes in the active cell fraction subsequent to environmental perturbation (e.g., by nutrient inputs or grazing).

The greatest variability in results in this study was observed with the Live/Dead assay, especially in the nutrient addition experimental series. Although this method works well with bacteria in cultures and has been used in marine environments (Choi et al. 1996, Gasol et al. 1999), it appears to be somewhat less successful when applied to heterogeneous freshwater bacterial populations. The NuCC method tended to give results similar to CTC and has the advantage of not requiring any incubation step before fixing the samples. It thus avoids problems associated with the potential toxicity of CTC (Ullrich et al. 1996, 1999). The CTC method, however, has the advantage that positively stained bacterial cells can be detected with greater sensitivity and counted with flow cytometry. Indeed, Sieracki et al. (1999) have shown that flow cytometric analysis consistently gives higher percentages of CTC+ cells compared to microscopic analysis.
It seems reasonable to assume, therefore, that the CTC results in this study are probably underestimates of the fraction of highly active bacteria in the lake waters.

The apparently low percentage of actively metabolizing bacteria observed in Lake Kinneret throughout the year and at all water column depths was consistent with the results generated by a recent carbon flux model for Lake Kinneret (Hart et al. 2000). In the published data for this model unrealistically high values for the ratios of bacterial biomass to production (B/P) were given, averaging $6.7,3.4,8.3$ and 11.8 for spring, summer, fall and winter seasons respectively. However, these B/P values were probably based on erroneously high values for bacterial cell carbon, and, even more significantly, on the assumption that all bacterial cells counted with DAPI were active. If we assume that no more than $\sim 20 \%$ of total bacterial cells were in fact metabolizing, and correct the cell biomass values based on a carbon content of $\sim 30 \mathrm{fg} \mathrm{C}^{\mathrm{C}} \mathrm{cell}^{-1}$ (Lee \& Fuhrman 1987, Fukada et al. 1998), then the B/P ratios become much more reasonable for actively metabolizing cells (B/P between 0.3 and $~ 1.0)$.

\section{Metabolic activity parameters}

We found reasonably close correlations of ETS activity with other frequently used determinants of microbial activity; direct $\mathrm{O}_{2}$ consumption, peptidase and $\beta$ glucosidase enzymatic activity (Table 2). Our results suggest that ETS measurements can serve as a good proxy for overall bacterial activity in bulk water but of course they give no detailed information concerning phylogenetic groups or the fraction of active bacteria within the microbial assemblage. Note however that in our case there was no relationship between ETS and bacterial productivity as measured by leucine incorporation.

Leucine incorporation rates correlated well with both chlorophyll concentrations and photosynthetic carbon fixation rates (Table 2), but not with algal wet weight biomass, similarly to previous observations in Lake Kinneret (Berman unpubl.) and in many other aquatic environments (Cole et al. 1988, Billin et al. 1990). It is noteworthy that we found that leucine incorporation rates correlated significantly with peptidase but not with $\beta$-glucosidase enzyme activities.

The ETS activity measured in the GF/C-filtered lake samples was directly related to the numbers of CTC+ and NuCC cells but not to the total (DAPI) bacteria. This would support the premise that only the more active fraction of the bacterial population was responsible for most of the bacterial respiration. Neither leucine incorporation rates nor peptidase activity correlated with the numbers of $\mathrm{CTC}+, \mathrm{NuCC}$ or MEM+ 
bacteria. Peptidase activity was significantly directly correlated to the counts of total (DAPI) bacteria, but not to $\mathrm{CTC}+$ or NuCC cell numbers, suggesting that this enzyme is expressed not only by strongly active cells but also by weakly metabolizing bacteria (e.g., cells in a state of starvation-survival, Morita 1997) or even by moribund bacteria. No significant relationship was found between any of the metabolic activity parameters and MEM+ cells.

Our observation that $\beta$-glucosidase activities were generally higher than those of peptidase (Table 3) confirms previous work of Simon et al. (2000). These investigators showed that this pattern was characteristic for Lake Kinneret, where a relatively high level of polysaccharide input was expected. In contrast, they found that proteinase activities tended to be higher than $\beta$-glucosidase in Lake Constance, where proteinaceous inputs may be more important.

Lipase activity was always detectable in the lake water although at somewhat lower levels than the other enzymes monitored (Table 3 ). We have no information about the potential importance of these 'free dissolved' lipases in the recyling of lipid-containing organic matter in lake water.

\section{Time course and nutrient addition experiments}

In the time course experiments (Fig. 3, Table 6) it was not surprising that the addition of tryptose, after an initial period of 10 to $15 \mathrm{~h}$, always gave a dramatic increase in bacterial numbers, rates of leucine uptake and in the percentages of CTC+ and NuCC bacteria. In this case, we suspect that the tryptose addition may have caused selective growth of one or more species of bacteria rather than of the entire initial assemblage (see below). However, our results from samples to which antibiotics were added would indicate that, even when bacterial replication was strongly inhibited, a sizable proportion of the bacteria that appeared to be inactive initially were capable of 'switching on' and being detected as 'active' cells.

This phenomenon was first reported by Choi et al. (1999) for a coastal marine environment. Presumably in most natural aquatic environments such situations are quite transient, and the normal state is that only a relatively low percentage of total bacteria are highly metabolically active at any given time. In this experiment (Table 6), after $40 \mathrm{~h}$, leucine incorporation was also stimulated in samples with added antibiotic, despite the relatively low increase in cell multiplication that should normally accompany protein synthesis. Possibly, in this case, protein synthesis may have led to an increase of cell biovolume but not of abundance.
The results from the nutrient addition experiments consistently showed strong stimulation by tryptose of the fraction of CTC+, NuCC or MEM+ bacteria and of ETS activity after 24 hincubation (Table 7). Frequently $\mathrm{P}$ or $\mathrm{N}$ or both nutrients increased the proportional abundances of CTC+ or NuCC cells, without any apparent seasonal pattern (Table 7). It is curious that in these experiments, glucose elicited much lower responses than the tryptose (protein hydrolysate) despite the generally greater activities of $\beta$-glucosidase than proteinase usually observed in the lake water (see above and Simon et al. 2000).

It would probably be erroneous to infer any pattern of in situ nutrient limitation of bacteria in Lake Kinneret solely from this set of experiments. The addition of various nutrient supplements may have given a selective advantage to specific groups within the initial bacterial assemblage that responded by increasing their numbers during the incubation period. This possibility can only be resolved if the phylogenetic composition of the bacterial assemblage is determined initially and at the end of the incubation. The application of molecular biological techniques to identify the changes in specific groups of bacteria taking place in time course and nutrient addition experiments (Amann et al. 1995, Ouverney \& Fuhrman 1999, Cottrell \& Kirchman 2000) will undoubtedly provide more precise details of nutrient limitation in natural microbial assemblages.

\section{Impact of protists on proportion of active bacteria}

There is evidence indicating that flagellates and other micrograzers preferentially graze metabolically active (e.g., growing or CTC+) cells (Sherr et al. 1992, Gonzalez et al. 1993, del Giorgio et al. 1996), which would tend to decrease the proportion of active cells in the bacterial population. On the other hand, the recycling of nutrients due to protistan excretion might serve to stimulate bacterial growth and to increase the fraction of active bacterial cells. From the results of our experiments with the addition of flagellates or Colpoda sp. to GF/C-filtered Lake Kinneret water it appeared that the second process prevailed, at least during the initial incubation period. As shown in Fig. 4, samples to which protists were added consistently showed higher percentages of 'active' bacteria after $24 \mathrm{~h}$.

A dramatic rise in the percentages of 'active' bacteria (similar to that previously observed) was also seen in this experimental series when bacterial growth was stimulated by the addition of a complex organic nutrient (tryptose). When flagellates were also added to tryptose-supplemented lake water, even higher proportions of the total bacterial population appeared to be active after $24 \mathrm{~h}$. In the case of added tryptose and 
ciliates (Colpoda sp.), the fraction of CTC+ bacteria only became signifcantly higher than in the tryptoseonly sample after $3 \mathrm{~d}$ (Fig. 4C). Thus it appears that the impact of protist grazing is indeed to increase the numbers of active bacteria, i.e., grazing tends to keep the bacterial community in a state of active growth, at least during the initial stages of the predator-prey interaction. This result supports the earlier finding of Sherr et al. (1982) that flagellate grazing stimulated the rate of degradation of phytoplankton detritus by Lake Kinneret bacteria.

\section{Conclusion}

Clearly each of the 3 methods used here to detect 'active' or living cells measures a different attribute of the physiological status of bacteria. Different aspects of bacterial activity, such as motility and substrate uptake, can be detected by other methods. Usually, it appears that only a relatively small proportion (perhaps not more than at most $20 \%$ ) of the total bacterial population in natural waters is 'active' by the criteria of the assay methods used in this study. Nevertheless, our results support the idea that even apparently inactive bacteria can become highly active under appropriate conditions (Choi et al. 1999). This 'switching on' might occur as a result of nutrient inputs caused by upwelling events, or on a more localized scale, because of inputs from protistan or zooplankton excretion or sloppy feeding (Jumars et al. 1989) or from algal cell lysis (Agusti et al. 1998).

As we have emphasised, there are different criteria for characterizing a bacterial cell as 'active'. Thus, we can envisage natural bacterial populations as a kaleidoscope image, with various components functioning at different degrees of activity at any given moment, constantly modulating their physiological activities to the exigencies of the environment. Del Giorgio \& Cole (2000) have proposed that the co-existence of sub-populations of highly active and slow-growing cells can explain the typically low growth efficiencies observed for bacterioplankton communities in aquatic environments. The complications presented by having a more realistic picture of a heterogeneous bacterial population, not only in terms of phylotype but also in levels of metabolic activity, will need to be incorporated into our perceptions of aquatic ecosystems.

Acknowledgements. We thank Dr H. P. Grossart and 3 reviewers for their perceptive and helpful comments on an earlier version of this manuscript. This work was supported by Grant 95-0002 from the United States-Israel Binational Science Foundation, Jerusalem, Israel. A contribution of Israel Oceanographic and Limnological Research.

\section{LITERATURE CITED}

Agusti S, Satta MP, Mura MP, Benavent E (1998) Dissolved esterase activity as a tracer of phytoplankton lysis: evidence of high phytoplankton lysis rates in the NW Mediterranean. Limnol Oceanogr 43:1836-1849

Amann RI, Ludwig W, Schliefer KH (1995) Phylogenetic identification and in situ detection of individual microbial cells without cultivation. Microbiol Rev 59:143-169

Berman T, Stone L, Yacobi YZ, Kaplan B, Schlichter M, Nishri A, Pollingher U (1995) Primary production and phytoplankton in Lake Kinneret: a long-term record (19721993). Limnol Oceanogr 40:1064-1076

Bernard L, Schafer H, Fabien J, Courties C, Muyzer G, Lebaron P (2000) Genetic diversity of total, active and culturable marine bacteria in coastal seawater. Aquat Microb Ecol 23:1-11

Billin G, Servais P, Becquevort S (1990) Dynamics of bacterioplankton in oligotrophic and eutrophic aquatic environments: bottom-up or top-down control? Hydrobiologia 207:37-42

Choi JW, Sherr EB, Sherr BS (1996) Relation between presence-absence of a visible nucleoid and metabolic activity in bacterioplankton cells. Limnol Oceanogr 41: 1161-1168

Choi JW, Sherr EB, Sherr BS (1999) Dead or alive? A large fraction of ETS-inactive marine bacterioplankton cells, as assessed by reduction of CTC, can become ETS-active with incubation and substrate addition. Aquat Microb Ecol 18:105-115

Cole JJ, Findlay S, Pace ML (1988) Bacterial production in fresh and saltwater: a cross system overview. Mar Ecol Prog Ser 43:1-10

Cottrell MT, Kirchman DL (2000) Natural assemblages of marine proteobacteria and members of the CytophagaFlavobacter cluster consuming low- and high-molecular weight dissolved organic matter. Appl Environ Microbiol 66:1692-1697

del Giorgio PA, Cole JJ (2000) Bacterial energetics and growth efficiencies. In: Kirchman DL (ed) Microbial ecology of the oceans. Wiley-Liss, New York, p 289-325

del Giorgio PA, Scarborough G (1995) Increase in the proportion of metabolically active bacteria along gradients of environment in freshwater and marine plankton: implications on estimate of bacterial growth and production rates. J Plankton Res 17:1905-1924

del Giorgio PA, Gasol JM, Mura P, Vaque D, Duarte CM (1996) Protozoan control of the proportion of metabolically active bacteria in coastal marine plankton. Limnol Oceanogr 41:1169-1179

del Giorgio PA, Prairie, YT, Bird DF (1997) Coupling between rates of bacterial production and the number of metabolically active cells in lake bacterioplankton, measured using CTC reduction and flow cytometry. Microb Ecol 34: $144-154$

Fukuda R, Ogawa H, Nagata T, Koike I (1998) Direct determination of carbon and nitrogen contents of natural bacterial assemblages in marine environments. Appl Environ Microbiol 64:3352-3358

Gasol JM, Zweifel UL, Peters F, Fuhrman JA, Hagström ^̊ (1999) Significance of size and nucleic acid content heterogeneity as measured by flow cytometry in natural planktonic bacteria. Appl Environ Microbiol 65: 4475-4483

Gonzalez JM, Sherr EB, Sherr BF (1993) Differential grazing by marine flagellates of growing vs starving bacteria, and on motile vs non-motile bacteria. Mar Ecol Prog Ser 102: $257-267$ 
Hart D, Stone L, Berman T (2000) Seasonal dynamics of the Lake Kinneret food web: the importance of the microbial loop. Limnol Oceanogr 45(2):350-361

Heissenberger A, Leppard GG, Herndl GJ (1996) Relationship between the intracellular integrity and the morphology of the capsular envelope in attached and free living marine bacteria. Appl Environ Microbiol 62:4521-4528

Hobbie JE, Daley RJ, Jasper S (1977) Use of nuclepore filters for counting bacteria by fluoroscence microscopy. Appl Environ Microbiol 33:1225-1228

Holm-Hansen O, Lorenzen CJ, Holmes RW, Strickland JDH (1965) Fluorometric determination of chlorophyll. J Cons Int Explor Mer 30:3-15

Hoppe HG (1993) Use of fluorogenic substrates for extracellular enzyme activity measurement in bacteria. In: Kemp PF, Sherr BF, Sherr EB, Cole JJ (eds) Handbook of methods in aquatic microbial ecology. Lewis Publishers, Ann Arbor, p 423-431

Jumars PA, Penry DA, Baross JA, Perry MJ, Frost W (1989) Closing the microbial loop: dissolved carbon pathway to heterotrophic bacteria from incomplete ingestion, digestion and absorbtion in animals. Deep-Sea Res 36:483-495

Karner M, Fuhrman JA (1997) Detrmination of active marine bacterioplankton: a comparison of universal 16s rRNA probes, autoradiography and nucleoid staining. Appl Environ Microbiol 63:1208-1213

Kenner RA, Ahmed SI (1975) Correlation between oxygen utilization and electron transport activity in marine phytoplankton. Mar Biol 33:129-133

Kirchman DL, K'nees E, Hodson RE (1985) Leucine incorporation and its potential as a measure of protein synthesis by bacteria in natural aquatic systems. Appl Environ Microbiol 49:559-607

Kogure K, Simidu U, Taga N, Colwell RR (1987) Correlation of direct viable counts with heterotrophic activity for marine bacteria. Appl Environ Microbiol 53:332-337

Lee S, Fuhrman JA (1987) Relationships between biovolume and biomass of naturally-derived marine bacterioplankton. Appl Environ Microbiol 53:1298-1303

Morita RY (1997) Bacteria in oligotrophic environments. Chapman and Hall, New York

Ouverney CC, Fuhrman JA (1999) Combined microautoradiography-16s rRNA probe techniques for determination of radioisotope uptake by specific microbial cell types in situ. Appl Environ Microbiol 65:1746-1752

Packard TT (1971) The measurements of respiratory electrontransport activity in marine phytoplankton. J Mar Res 29:235-244

Porter KG, Feig YS (1980) The use of DAPI for identifying and counting aquatic microflora. Limnol Oceanogr 25:943-948

Porter J, Diaper J, Edwards C, Pickup R (1995) Direct mea-

Editorial responsibility: Fereidoun Rassoulzadegan,

Villefranche-sur-Mer, France surements of natural planktonic bacterial community viability by flow cytometry. Appl Environ Microbiol 61: 2783-2786

Rodriguez GG, Phipps D, Ishiguro K, Ridgway HF (1992) Use of fluorescent redox probe for direct visualization of actively respiring bacteria. Appl Environ Microbiol 58: 1801-1808

Sherr BF, Sherr EB, Berman T (1982) Decomposition of organic detritus: a selective role for microflagellate protozoa. Limnol Oceanogr 27:765-769

Sherr BF, Sherr EB, McDaniel J (1992) Effect of protistan grazing on the frequency of dividing cells (FDC) in bacterioplankton assemblages. Appl Environ Microbiol 58: 2381-2385

Sherr EB, Sherr BF, Sigmon CT (1999a) Activity of marine bacteria under incubated and in situ conditions. Aquat Microb Ecol 20:213-223

Sherr BF, del Giorgio P, Sherr EB (1999b) Estimating abundance and single-cell characteristics of respiring bacteria via the redox dye CTC. Aquat Microb Ecol 18:117-131

Sieracki ME, Cucci TL, Nicinski J (1999) Flow cytometric analysis of 5-cyano-2, 3-ditolyl tetrazolium chloride activity of marine bacterioplankton in dilution cultures. Appl Environ Microbiol 65:2409-2417

Simon M, Azam F (1989) Protein content and protein synthesis rates of planktonic marine bacteria. Mar Ecol Prog Ser 51:201-213

Simon M, Jontofson M, Parparov A, Berman T (2000) Turnover of combined amino acids and carbohyrates in organic aggregates and in the bulk water in Lake Kinneret and other pelagic ecosystems. Arch Hydrobiol Spec Ser Adv Limnol 55:365-377

Smith EM (1998) Coherence of microbial respiration rate and cell-specific bacterial activity in a coastal plankton community. Aquat Microb Ecol 16:27-35

Ullrich S, Karrasch B, Hoppe HG, Jeskulke K, Mehrens M (1996) Toxic effects on bacterial metabolism of the redox dye 5-cyano-2, 3-ditolyl tetrazolium chloride. Appl Environ Microbiol 62:4587-4593

Ullrich S, Karrasch B, Hoppe HG (1999) Is the CTC dye technique an adequate approach for estimating active bacterial cells? Aquat Microb Ecol 17:207-209

Williams SC, HongY, Danavall DCA, Howard-Jones $\mathrm{MH}$, Gibson D, Frischer ME, Verity PG (1998) Distinguishing between living and nonliving bacteria: evaluation of the vital stain propidium iodide and the combined use with molecular probes in aquatic samples. J Microbiol Methods 32:225-236

Zweifel UL, Hagström Å (1995) Total counts of marine bacteria include a large fraction of non-nucleoid containing bacteria (ghosts). Appl Environ Microbiol 61:2180-2185

Submitted: October 4, 2000; Accepted: February 8, 2001

Proofs received from author(s): February 24, 2001 